\title{
PENGGUNAAN MODEL PEMBELAJARAN NHT UNTUK MENINGKATKAN HASIL BELAJAR BIOLOGI KELAS XI IPA SMA ISLAM 1 PRAMBANAN TAHUN PELAJARAN 2009/2010
}

\author{
Sumarjito \\ SMA Islam 1 Prambanan Jawa Tengah
}

\begin{abstract}
This classroom action research aims to determine the increase in student activity, where the learning process-centered and see an increase in student learning outcomes of biology in the $11^{\text {th }}$ science class at The first Prambanan Islamic Senior High School in 2009/2010 academic year with learning models numbered heads together (NHT). The study consisted of two cycles, the first cycle had done by the two meetings held on 26 and May 27, 2010 with material "structure and function of reproductive men and women" and "spermatogenesis, oogenesis and ovulation ". Cycle II carried as many as two meetings held on 1 and June 2, 2010 by presenting "menstruation, fertilization, gestation" and "child birth, ASI (mother's milk), contraception, disorders of the reproductive system". Subjects were the $11^{\text {th }}$ grade science class of The first PRAMBANAN ISLAMIC SENIOR HIGH SCHOOL in 2009/2010 academic year on Sleman - Yogyakarta , which amounted to thirteen students. Based on this study concluded that the application of learning models numbered heads together (NHT) can make the students active in the learning process, student-centered learning (learning that focus on student) and improve learning outcomes.
\end{abstract}

Kata kunci: Numbered Heads Together (NHT), Hasil Belajar

Seorang guru yang mengajar karena panggilan jiwanya, ada misi untuk mengantarkan anak didiknya kepada kehidupan yang lebih baik secara intelektual dan sosial (Abdullah Munir, 2006: xvi), maka setiap guru menginginkan tujuan pembelajarannya berhasil, baik ditinjau dari segi proses maupun capaian target kompetensi dasarnya. Untuk itu guru dituntut untuk dapat memecahkan permasalahan yang mungkin timbul dalam mengelola proses pembelajarannya. Kreatifitas sangat dibutuhkan untuk memunculkan solusi cemerlang guna memecahkan problem pembelajarannya.

Sikap kurang bergairah, pasif, berbicara pada teman, main sms dan kelas tidak berpusat pada siswa adalah hal yang banyak terjadi di lingkungan SMA ISLAM I PRAMBANAN SLEMAN. Banyak faktor yang menjadi penyebab, diantaranya adalah kualitas masukan siswa yang rendah ( rata-rata NEM masuk PDB 2007 = 25,16; tahun $2008=25,20$; tahun $2009=19,67)$, semangat belajar siswa yang rendah dan kemungkinan pemilihan model pembelajaran yang kurang tepat.

Jika kondisi pembelajaran seperti tersebut tidak dicarikan pemecahannya, maka akan berdampak pada rendahnya tingkat capaian tujuan belajar, baik dari segi proses belajar maupun capaian target kompetensi dasarnya. Berikut ini disajikan data hasil evaluasi kognitif empat kompetensi dasar semester dua (2) klas XI IPA tahun pelajaran 2009/2010, yaitu (1) K.D. 3.3 : Sistem Digesti $=61,20$ (2) K.D. 3.4 : Sistem Pernafasan $=53,40$ (3) K.D. 3.5 : Sistem Ekskresi $=38,20$ (4) K.D. 3.6 : Sistem Koordinasi $=53,50$.

Numbered heads together (NHT) adalah model pembelajaran yang dikembangkan untuk melibatkan banyak siswa dalam menelaah materi yang tercakup dalam suatu pelajaran dan mengukur pemahaman mereka terhadap materi pelajaran tersebut. Model pembelajaran "numbered heads together" diharapkan dapat membuat 
siswa lebih aktif, bergairah dan siswa tidak menjadikan guru sebagai satusatunya sumber informasi, sehingga semua akan bermuara pada tercapainya tujuan pembelajaran, baik dari segi proses maupun target capaian penguasaan kompetensi dasar. NHT adalah model pembelajaran yang dikembangkan untuk melibatkan banyak siswa dalam menelaah materi yang tercakup dalam suatu pelajaran dan mengukur pemahaman mereka terhadap materi pelajaran tersebut (Ibrahim, dkk, 2000 dalam Maulida Hayati, 2008 : 1). Menurut Kagan (1992, dalam Anonim, 2009: 81) langkah-langkah pembelajaran menggunakan model NHT adalah sebagai berikut ;

1. Siswa dibagi dalam kelompok yang terdiri dari $3-4$ anggota, setiap siswa / anggota kelompok mendapat sebuah nomor.

2. Guru memberikan tugas dan masingmasing kelompok mengerjakannya.

3. Kelompok mendiskusikan jawaban yang benar dan memastikan setiap anggota kelompok dapat mengerjakannya / megetahui jawabannya.

4. Guru memanggil salah satu siswa dengan memanggil nomornya, kemudian siswa tersebut melaporkan hasil kerjasama diskusi kelompoknya

5. Kelompok atau teman yang lain memberikan tanggapan, kemudian guru melanjutkan memanggil nomor yang lain.

6. Siswa dengan dipandu guru membuat kesimpulan.

Hasil penelitian Maulida Hayati (2008 : 3) menyimpulkan bahwa pembelajaran biologi dengan mengintegrasikan kuis ke dalam pembelajaran kooperatif numbered heads together dapat : (1) meningkatkan aktivitas siswa dalam berkelompok, mengerjakan tugas-tugas, berfikir bersama dan menjawab kuis (2) meningkatkan hasil belajar siswa (3) mendapat respon positif.

Belajar adalah proses mendapatkan kemampuan sampai menjadi milik pribadi (Winkel, 1991 : 34). Belajar di sekolah adalah wujud aktivitas siswa saat terjadinya proses pembelajaran. Pembelajaran sejati adalah lebih berdasar pada pembelajaran yang terbimbing dengan pendampingan dari pada sekedar transmisi pengetahuan. Pembelajaran merupakan individual discovery (Afiatin, tanpa tahun),

Prestasi belajar adalah proses mental yang mengarah pada penguasaan pengetahuan, ketrampilan dan sikap yang dimiliki oleh siswa setelah menerima pengalaman belajar terhadap mata pelajaran yang dibuktikan melalui hasil tes (Sudjana, 2005 dalam Triyana, 2008: 20).

\section{METODE}

Lokasi penelitian di SMA Islam 1 Prambanan Sleman Yogyakarta, subyek yang dikenai tindakan adalah siswa kelas XI IPA semester dua (2) SMA Islam 1 Prambanan Sleman Tahun Pelajaran 2009/2010

\section{Sasaran Penelitian}

1. Perubahan partisipasi siswa dalam mengikuti proses pembelajaran

2. Perubahan prosentase waktu yang menjadi porsi siswa dan yang menjadi porsi guru selama proses pembelajaran

3. Perubahan hasil belajar siswa setelah proses pembelajaran

\section{Rencana Tindakan}

1. Tahap Pendahuluan

a. Pertemuan dengan Kepala Sekolah untuk memberi tahu tentang akan adanya Penelitian Tindakan Kelas (PTK) 
b. Refleksi Awal

Pendeskripsian tentang masalah model pembelajaran sebelumnya, partisipasi siswa dalam pembelajaran dan prestasi hasil belajar siswa.

\section{Tahap Pelaksanaan Tindakan}

\section{Siklus I}

a. Perencanaan Tindakan

1). Perancangan pembelajaran dengan model pembelajaran NHT, rancangan pembelaran disusun dalam bentuk RPP

2). Penyusunan alat perekam data, yang meliputi lembar tes dan lembar observasi

3). Penyusunan hand out materi pembelajaran

4). Penyusunan rencana pengolahan data

b. Pelaksanaan Tindakan

1). Penomoran

2). Pengajuan pertanyaan berupa lembar diskusi

3). Berfikir bersama agar setiap anggota tim tahu jawabannya

4). Pemberian jawaban, guru menyebut nomor tertentu kemudian siswa yang nomornya sesuai mengacungkan tangan, kemudian siswa lain yang bernomor sama untuk menanggapinya.

5). Penarikan kesimpulan yang dipandu guru

6). Pelaksanaan tes

c. Observasi

Yang diobservasi pada pelaksanaan tindakan ini adalah kegiatan peneliti dan aktivitas siswa

\section{d. Refleksi}

Data dianalisis untuk melihat tingkat efektifitas rancangan pembelajaran biologi yang telah dilakukan, yang selanjutnya dipakai untuk perencanaan siklus II.

\section{Siklus II}

Berdasarkan hasil refleksi siklus I digunakan untuk merencanakan siklus II.

\section{Prosedur Pengumpulan Data}

1. Partisipasi Siswa

Diperoleh dari hasil observasi perilaku siswa dalam kelas yang berkaitan dengan pemberian tindakan selama pembelajaran berlangsung.

2. Perbandingan porsi waktu siswa dan guru

Data tersebut diperoleh dengan jalan membandingkan waktu yang dimanfaatkan guru dan siswa selama proses pembelajaran.

3. Prestasi Belajar

Data tentang prestasi belajar diperoleh dari hasil tes di setiap akhir tindakan

\section{Analisis Data}

1. Partisipasi Siswa

Data yang diperoleh ditampilkan dalam bentuk tabel, kemudian dianalisis secara deskriptif berdasarkan taraf kemunculan indikator.

2. Perbandinngan porsi penggunaan waktu antara siswa dan guru

Data yang diperoleh dari hasil observasi ditampilkan dalam bentuk tabel

3. Prestasi Belajar

a. Data diperoleh dari hasil tes kemudian dihitung tingkat ketuntasannya dan dibandingkan dengan KKM yang ditetapkan.

b. Untuk melihat perubahan nilai tiap indivdu dari siklus I ke II, maka nilai ditampikan dalam bentuk grafik. 
HASIL

\section{Partisipasi Siswa Dalam Proses Pembelajaran}

Data partisipasi siswa dalam proses pembelajaran disajikan dalam bentuk grafik sebagai berikut :

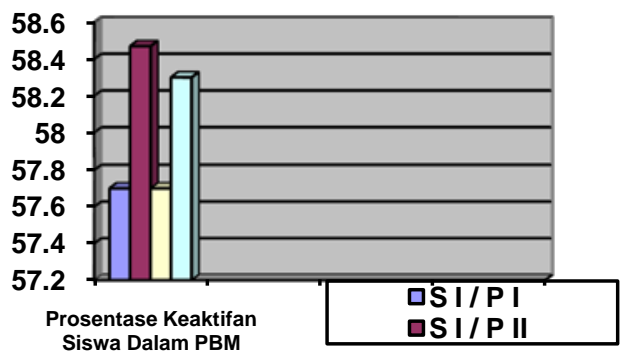

\section{Penggunaan Waktu antara Siswa dan} Guru

Data penggunaan waktu siswa dan guru disajikan dalam bentuk grafik berikut :

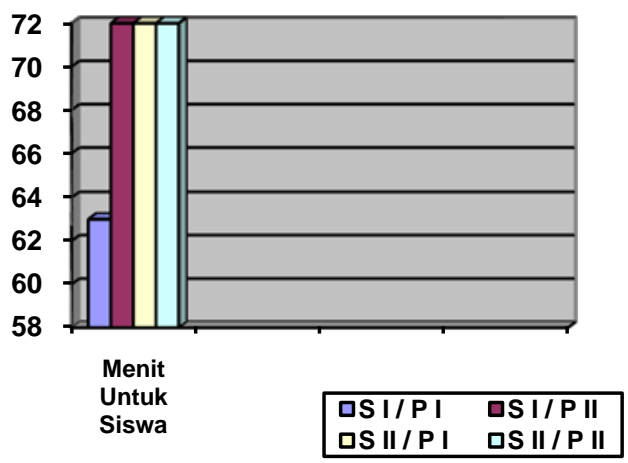

\footnotetext{
* Keterangan :

$\mathrm{S}=$ Siklus dan $\mathrm{P}=$ Pertemuan
}

\section{Data Prestasi Belajar Siswa}

Data prestasi belajar siswa disajikan dalam bentuk grafik berikut:

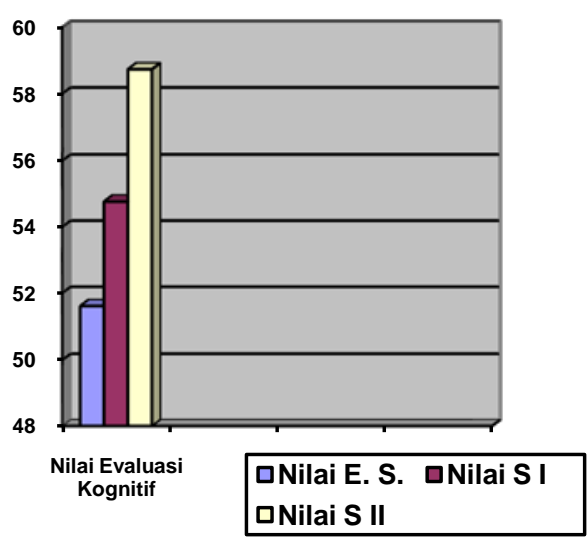

\section{PEMBAHASAN}

Sesuai dengan rancangan penelitian yang telah disusun dan hasil penelitian yang diperoleh maka pada pembahasan ini akan dititikberatkan pada tiga hal yaitu (1) partisipasi siswa dalam proses pembelajaran (2) prosentase penggunaan waktu antara guru dan siswa selama proses belajar mengajar dan (3) prestasi belajar siswa.

\section{Partisipasi Siswa dalam Proses Belajar - Mengajar}

Partisipasi siswa dalam proses belajar mengajar (PBM) dilihat melalui 10 aspek, yaitu (1) melakukan presentasi (2) menanggapi pendapat siswa lain (3) keaktifan berdiskusi (4) aktif mengikuti presentasi (5) menggunakan referensi untuk menjawab soal (6) membantu siswa lain dalam memahami materi (7) keaktifan mencatat penjelasan guru (8) aktif memperhatikan PBM (9) bersama guru dalam penarikan kesimpulan (10) keaktifan mengerjakan soal evaluasi. Berdasarkan analisis data yang diperoleh menunjukkan bahwa pada siklus I 
partisipasi siswa sebesar 58,1\% yang berarti dalam kategori C (skore C : 41$60 \%$ ) dan pada siklus II sebesar 58,0\% yang berarti juga dalam kategori C. Walaupun antara siklus I dan II partisipasi siswa tidak menunjukkan peningkatan namun hal tersebut secara umum sudah menunjukkan kemajuan yang menggembirakan bila dirunut dari awal sebelum digunakannya model pembelajaran NHT dimana siswa dalam pembelajaran tidak bergairah, pasif, berbicara pada teman, dan main sms. Meningkatnya partisipasi siswa dalam pembelajaran tersebut juga telah dibuktikan dari hasil penelitian Hayati (2008:3).

\section{Penggunaan Waktu Antara Guru Dan Siswa}

Distribusi penggunaan waktu antara guru dan siswa akan menunjukkan dimanakah pembelajaran berpusat. Dari hasil analisis data dapat dilihat bahwa pada siklus I perbandingan penggunaan waktu antara guru dan siswa adalah 22,9 : 67,1, sedangkan pada siklus II adalah 18 : 72, hal ini berarti bahwa pada siklus I penggunaan waktu dalam kategori B, dan pada siklus II meningkat menjadi kategori A. Indikator ini menunjukkan bahwa baik pada siklus I maupun II pembelajaran telah berpusat pada siswa, yang merupakan pembelajaran sejati, yaitu pembelajaran yang terbimbing dengan pendampingan bukan sekedar transmisi pengetahuan (Tina Afiatin, $\mathrm{tt}: 1)$.

\section{Prestasi Belajar Siswa}

Data menunjukkan bahwa rata-rata prestasi belajar siswa pada siklus I adalah 54,76 dan pada siklus II adalah 58,73. Hasil ini sangat menggembirakan. Data ini menunjukkan bahwa penggunaan model pembelajaran NHT dapat meningkatkan hasil belajar siswa, hal ini sesuai dengan pendapat
Maulida Hayati (2008: 3). Lebih menggembirakan lagi apa bila hasil belajar tersebut dirunut dari nilai rata-rat empat(4) K.D. sebelumnya yang hanya 51,60. Data-data ini menunjukkan bahwa penggunaan model pembelajaran selama dua (2) siklus telah mencapai hasil yang diharapkan, yaitu dengan meningkatya hasil belajar di atas kriteria ketuntasan minimal (KKM) yang telah ditentukan untuk mata pelajaran biologi di klas XI IPA SMA ISLAM 1 PRAMBANAN tahun pelajaran 2009/2010 yang sebesar 50 .

\section{KESIMPULAN DAN SARAN}

\section{Kesimpulan}

Berdasarkan hasil perbaikan pembelajaran dan pembahasan, maka dapat ditarik kesimpulan sebagai berikut

1. Penggunaan model pembelajaran numbered heads together (NHT) membuat siswa aktif berpartisipasi dalam proses pembelajaran.

2. Penggunaan model pembelajaran numbered heads together (NHT) membuat pembelajaran berpusat pada siswa.

3. Penggunaan pembelajaran numbered heads together (NHT) meningkatkan hasil belajar siswa.

\section{Saran}

Berdasarkan kesimpulan yang diperoleh maka disarankan adanya tindak lanjut sebagai berikut :

1. Bagi guru :

a. Guru diharapkan rajin melakukan penelitian tindakan kelas (PTK) untuk memecahkan masalahmasalah yang muncul dalam tugasnya.

b. Guru diharapkan dapat memilih model pembelajaran yang membuat siswa aktif, sehingga 
pembelajaran dapat lebih bermakna.

2. Bagi siswa :

a. Siswa diharapkan meningkatkan keberaniannya untuk mengemukakan pendapatnya.

b. Siswa diharapkan menggali informasi dari berbagai sumber, bukan hanya dari guru.

c. Siswa diharapkan akrab dengan perbedaan pendapat yang muncul dari orang-orang disekelilingnya.

3. Bagi Sekolah :

Sekolah diharapkan mendorong gurugurunya untuk melakukan penelitian tindakan kelas (PTK) agar kualitas pembelajaran semakin meningkat.

\section{DAFTAR RUJUKAN}

Arikunto, Suharsimi, dkk. 2006. Penelitian Tindakan Kelas (hlm. 36-40). Jakarta : Bumi Aksara

Munir, Abdullah. 2006. Spiritual Teaching (hlm. xvi). Yogyakarta : Pustaka Insan - Madani.

Winkel, W.S. $1991 . \quad$ Psikologi Pengajaran (hlm. 34), Jakarta : Gramedia.

Lampiran Permendiknas No. 22 / 2006 (S.K. dan K.D.). Jakarta : Depdiknas

Materi Bimtek KTSP 2009. Direktorat Pembinaan SMA, Jakarta : Depdiknas

Antin Triyana. 2008. Penerapan Model Pembelajaran Kooperatif Numbered Heads Together (NHT) Untuk Meningkatkan Motivasi dan Hasil Prestasi Belajar Biologi Siswa Kelas VII SMP Miftahul Huda Kec. Ngadiraja, Pacitan (laporan penelitian ). (Online) : http://biologiforum.wordpress.com /25 , diakses April 2010
Hayati, Maulida. 2008. Meningkatkan Hasil Belajar Siswa Kelas I SMP $N 1$ Danau Panggang Melalui Kuis Numbered Heads Together (laporan penelitian, halaman 1-3), (Online), (http://suhadinet.wordpress.com/2 008/04/25), diakses tanggal : 2 April 2010

Afiatin, Tina (t.t.), Pembelajaran Berbasis Student Centered Learning (makalah halaman 12,6). (Online), www.inparametric.Com.), diakses 24 April 2010 